\title{
Caracterização patológica e imunoistoquímica da infecção pelo vírus da diarréia viral bovina*
}

\author{
MILENE SCHMITZ
}

\author{
David Driemeier (Orientador - UFRGS)
}

Banca: Ana Lúcia Schild (UFPel), Aldo Gava (UDESC/CAV), Cláudio Severo Lombardo de Barros (UFSM).

Foram testadas na imunoistoquímica (IHQ) para diarréia viral bovina (BVDV) 654 biópsias de tecidos cutâneos da orelha de bovinos e tecidos de 161 fetos bovinos abortados. Concomitantemente, foram avaliados pela necropsia, histologia e IHQ 19 casos ocorridos entre janeiro de 1996 e dezembro de 2003 e dois casos acompanhados entre janeiro de 2004 e agosto de 2005, remetidos ao Setor de Patologia Veterinária (SPV) da Universidade Federal do Rio Grande do Sul. No total, duas biópsias, seis bovinos e três fetos bovinos abortados apresentaram antígenos do BVDV na IHQ. As lesões macroscópicas desses animais ocorreram principalmente no trato digestivo, como enterite e ulcerações na cavidade oral, gengiva e língua. Atrofia de timo e linfadenomegalia também foram observadas. Histologicamente, hiperplasia linfóide e perda da estrutura folicular nos linfonodos, necrose das placas de Peyer, gliose e neuronofagia (cérebro) e nefrite e degeneração tubular renal foram algumas das lesões observadas. Na IHQ a marcação positiva do antígeno viral foi evidenciada principalmente na pele, cérebro, cerebelo, intestino delgado, linfonodos e baço. A prevalência de casos de BVDV em bovinos representou 23,8\% do total de 21 bovinos suspeitos necropsiados entre janeiro de 1996 a agosto de 2005 e 1,86\% dos fetos abortados examinados entre junho 1999 e maio 2004 no SPV-UFRGS.

Descritores: BVDV, bovinos, imunoistoquímica, achados patológicos.

Apresentada: 24 fevereiro 2006

"Dissertação de Mestrado n. 428 (Especialidade: Patologia Animal). 64f. Programa de Pós-graduação em Ciências Veterinárias [www.ufrgs.br/ ppgcv], Faculdade de Veterinária, Universidade Federal do Rio Grande do Sul (UFRGS), Porto Alegre, RS/Brasil. CORRESPONDÊNCIA: M. Schmitz [mineschmitz@hotmail.com]. 


\title{
Immunohistochemical and pathological aspects of bovine viral diarrhea virus**
}

\author{
MILENE SCHMITZ
}

\author{
David Driemeier (Adviser - UFRGS)
}

Committee: Ana Lúcia Schild (UFPel), Aldo Gava (UDESC/CAV), Cláudio Severo Lombardo de Barros (UFSM).

Six hundred and fifty four fragments of bovine ears and 161 fragments of tissues from bovine aborted fetuses submitted to diagnosis were examined through an immunohistochemistry (IHQ) test for bovine viral diarrhea virus (BVDV) antigen The tissues from 19 bovines with clinical BVD submitted to the Department of Veterinary Pathology, Universidade Federal do Rio Grande do Sul, between January 1996 and December 2003, and two bovine submitted between January 2004 and August 2005 , were examined through routine necropsy, histology and BVDV-IHQ. Tissues from six bovine and those from three aborted fetuses were positive in the BVDV-IHQ test. The main gross lesions included ulcers in the oral cavity, gums, and tongue, enteritis, thymus atrophy, and enlarged lymph nodes. Histological findings were lymphoid hyperplasia and follicular obliteration of nodal architecture, necrosis of Peyer's patches of the intestine, gliosis and neuronophagia in the brain, and nephritis with tubular degeneration. Skin, brain, cerebellum, small intestine, lymph nodes and/or spleen sections from six BVDV infected cattle and three aborted fetuses showed were positive in the BVDV-IHQ test. In this study, 23,80\% of bovine submitted to necropsy between January 1996 and August 2005, and 1,86\% of bovine aborted fetuses were BVDV infected.

Key words: BVD, bovine, immunohistochemistry, pathological findings. 